\title{
Undernutrition during the preweaning period changes calcium ATPase and ADPase activities of synaptosomal fractions of weanling rats
}

\author{
BY J. B. T. ROCHA, C. F. MELLO, J. J. F. SARKIS AND R. D. DIAS \\ Departamento de Bioquímica, Instituto de Biociencias, Universidade Federal do Rio Grande do Sul, \\ Rua Sarmento Leite, 500, Porto Alegre 90050, RS, Brazil
}

(Received 14 March $1989-$ Accepted 28 July 1989)

\begin{abstract}
The presence of activities that hydrolyse externally added ATP to adenosine in synaptosomal preparations from various sources is well demonstrated. The hydrolysis of ATP to AMP can be mediated either by the concerted action of enzymes or by an ATP-diphosphohydrolase (EC 3.6.1.5; apyrase). Undernutrition during the preweaning period can delay the development of several enzymes involved in the metabolism of neurotransmitters or neuronal function. In young rats, the presence of an apyrase in synaptosomal preparations from cerebral cortex was investigated. The results suggested that the hydrolysis of externally added ATP and ADP can be mediated by a single enzyme. The effects of preweaning undernutrition on the hydrolysis of ATP and ADP were also investigated. In weanling rats, previous undernutrition caused a decrease of about $20 \%$ in the hydrolysis of both substrates in synaptosomal fractions.
\end{abstract}

ATP-diphosphohydrolase: Preweaning undernutrition: Synaptosomal ATPase and ADPase: Rat

During the postnatal period several anatomical, biochemical and physiological modifications occur in the central nervous system of altricial mammals. Some of the most prominent events that occur during this period of rapid brain growth are the formation of functional synapses and the increase in the activity of various enzymes involved in neurotransmitter metabolism and neuronal function (Abdel-Latif et al. 1970; Vernadakis \& Arnold, 1980; Fiedler et al. 1987). Perinatal undernutrition impairs the generation of glial cells and myelin formation more than neuronal generation (Robain \& Ponsot, 1978; Wiggins, 1982), impairing synaptogenesis and consequently the development of neuronal contacts (Cragg, 1972; Salas et al. 1974; Dyson \& Jones, 1976). Perinatal undernutrition can also cause a marked reduction in the activity of various enzymes involved in neurotransmitter and energy metabolism, changing neurotransmitter and neuromodulator systems (Sereni et al. 1966; Adlard \& Dobbing, 1971, 1972; Kissane \& Hawrylewicz, 1975; Miller et al. 1977; Vanella et al. 1983; Vitiello \& Gombos, 1987; Chanez et al. 1988; Vendite et al. 1988).

Recently, a low-affinity, $\mathrm{Ca}^{2+}$-requiring, $\mathrm{Mg}^{2+}$-independent ATPase has been described as associated with purified synaptic plasma membrane preparations from rat brain (Sorensen \& Mahler, 1981). Additional studies of this calcium ATPase have demonstrated that the active site for hydrolysis of ATP is localized at the external surface of nerve-ending particles isolated from chicken forebrain, electric organ of Torpedo marmorata, and from various mammalian brain tissues (Sorensen \& Mahler, 1982; Keller \& Zimmerman, 1983; Nagy et al. 1983, 1986; Grondal \& Zimmerman, 1986). The external localization and the insensitivity of this ecto-ATPase to inhibitors of ion-transporting ATPase (oligomycin, ouabain, sodium azide, sodium vanadate, and others) suggest that this activity is different from that of classical ATPases. Other studies have demonstrated that both ADPase and 5'- 
nucleotidase (EC 3.1.3.5) activities are associated with isolated nerve-ending particles (Dowdal, 1978; Grondal \& Zimmerman, 1986) and with synaptic membranes (Nagata et al. 1984). It has also been demonstrated that ATP and ADP can be degraded to AMP by the action of an ATP-diphosphohydrolase ( $E C$ 3.6.1.5; apyrase) in synaptosomal fractions from the hypothalamus of adult rats (Sarkis et al. 1986 b: Schadeck et al. 1989). All these findings suggest that synaptosomal preparations contain enzymes that can be involved in the metabolism of ATP released in the synaptic cleft and that may be components of an enzyme chain that hydrolyses ATP to adenosine.

Since the maturation of various enzymes in the central nervous system seems to be delayed by perinatal undernutrition, we examined whether undernutrition during suckling changes the activity of hydrolysis of $\mathrm{Ca}-\mathrm{ATP}$ and $\mathrm{Ca}-\mathrm{ADP}$ in various subcellular fractions of cerebral cortex of 20 -d-old rats. Since it has been proposed that the hydrolysis of externally added ATP and ADP to AMP in synaptosomal preparations obtained from the hypothalamus of adult rats may be mediated by an apyrase (Sarkis et al. 1986 ; Schadeck et al. 1989), we also examined whether an apyrase is present in synaptosomal preparations from the cerebral cortex of young rats.

\section{EXPER IMENTA L}

\section{Chemicals}

Nucleotides, ouabain, sodium azide, dithiothreitol (DTT), succinic acid, glucose-6phosphate, $p$-nitrophenylphosphate and $\mathrm{P}^{1} \mathrm{P}^{5}$-di(adenosine-5')-pentaphosphate (Ap5A) were obtained from Sigma Chemical Co. (St Louis, MO, USA). EDTA, calcium chloride, potassium chloride, pyrophosphate (PPi) and $\beta$-glycerophosphate were obtained from Merck (Rio de Janeiro, RJ, Brazil). Percoll was obtained from Pharmacia (Uppsala, AB, Sweden) and was routinely filtered through millipore AP15 pre-filters in order to remove aggregated, incompletely coated particles. All other reagents were of analytical grade.

\section{General procedures}

For assessing the homogeneity and condition of our synaptosomal preparations, Wistar rats $(21 \mathrm{~d}$ of age) were used. They were maintained since birth on a $200 \mathrm{~g}$ protein $/ \mathrm{kg}$ laboratory chow (Germani, Porto Alegre, RS, Brazil; for details see Dutra-Filho et al. 1989).

Rats were killed by decapitation and the brain was quickly removed. The cerebral cortex was dissected and placed in an ice-cold medium consisting of $0.32 \mathrm{M}$-sucrose, $1 \mathrm{~mm}$-EDTA, and 0.25 mm-DTT, $\mathrm{pH} 7.4$ (medium I). Rat cerebral cortex was homogenized in $10 \mathrm{vol}$. medium I with ten up-and-down strokes at approximately $1200 \mathrm{rev} / \mathrm{min}$ in a Teflon-glass homogenizer. The homogenate was centrifuged at $1000 \mathrm{~g}$ for $10 \mathrm{~min}$ to give the low-speed supernatant fraction $\mathrm{S} 1$. The $\mathrm{S} 1$ fraction was centrifuged for $20 \mathrm{~min}$ at $12000 \mathrm{~g}$ to give the $\mathrm{P} 2$ pellet. The $\mathrm{P} 2$ pellet was resuspended in a volume of medium $\mathrm{I}$ to give a protein concentration of approximately $3-4 \mathrm{mg} / \mathrm{ml}$. Throughout the preparation the material was maintained at $0-4^{\circ}$.

\section{Percoll gradient preparation}

Discontinuous four-step Percoll gradients consisting of $160(1.3 \mathrm{ml}), 100(1 \mathrm{ml}), 50(1 \mathrm{ml})$ and $20(1 \mathrm{ml}) \mathrm{ml}$ Percoll $/ 1$ medium I were made in $5 \mathrm{ml}$ nitrocellulose tubes. The solutions of gradient were adjusted to $\mathrm{pH} 7.4$ with hydrochloric acid, or sodium hydroxide, just before use. 


\section{Isolation of synaptosomes}

The $\mathrm{P} 2$ fraction $(0 \cdot 7 \mathrm{ml})$ was layered gently over a freshly prepared gradient. The tubes were centrifuged in an ultracentrifuge swinging bucket rotor (Beckman, SW 50.1) at $22000 \mathrm{~g}$ for $20 \mathrm{~min}$. The interfacial fractions and the pellet (fractions $1-5$ with the numbering from top to bottom of the tube) were collected from the gradients by wide-tip disposable plastic transfer pipettes. As the fractions that banded between interfacial fractions contain little protein, only the interfacial fractions were analysed for lactate dehydrogenase ( $E C$ 1.1.1.27; LDH). The synaptosomal peak was determined by measuring occluded LDH (Morgan, 1976) in the presence of Triton X-100 $(10 \mathrm{ml} / \mathrm{l})$.

\section{Enzyme assays}

Samples were taken from the gradient and diluted when necessary to give an appropriate protein concentration. Since Percol was not removed, all enzyme assays were carried out in the presence of 0.5-2 ml Percoll/1. Control experiments demonstrated that this amount of Percoll did not interfere with any of the enzyme assays carried out in the present study. Nevertheless, the requisite amount of Percoll was added to the fractions that did not contain Percoll (homogenate, S1, P2 and microsomes). Unless otherwise stated, all enzyme assays were carried out in iso-osmotic mixtures.

\section{Marker enzymes}

Assay of LDH was carried out according to Whitaker (1969). Succinate dehydrogenase (EC 1.3.99.1; SDH) was assayed according to Sorensen \& Mahler (1982). $\mathrm{Na}^{+}, \mathrm{K}^{+}-$ ATPase (EC 3.1.6.4) was assayed according to Nagy \& Delgado-Escueta (1984). Acetylcholinesterase (EC 3.1.1.7; AChE) was assayed according to Ellman et al. (1961), Glucose-6-phosphatase (EC 3.1.3.9; G6Pase) was determined by the method of Hubscher \& West (1965).

\section{ATPase and ADPase}

Unless otherwise stated, the reaction medium for ATPase and ADPase assay contained $5 \mathrm{~mm}-\mathrm{KCl}, 1.5 \mathrm{~mm}$ - $\mathrm{CaCl}_{2}, 0.1 \mathrm{~mm}$-EDTA, $10 \mathrm{~mm}$-glucose, $225 \mathrm{~mm}$-sucrose, $45 \mathrm{~mm}$-Tris$\mathrm{HCl}$ buffer $(\mathrm{pH} 8.0)$ and $5 \mathrm{~mm}$-sodium azide. Appropriate fractions $(50 \mu \mathrm{l} ; 10-20 \mu \mathrm{g}$ protein) were added to the reaction medium and the mixture was pre-incubated for $10 \mathrm{~min}$ at $37^{\circ}$. The enzyme reaction was started by the addition of ATP or ADP to a final concentration of $1 \mathrm{mM}$. Incubation periods were chosen in order to ensure the linearity of the reaction. The reaction was stopped by the addition of trichloroacetic acid (TCA) to give a final concentration of $50 \mathrm{ml} / 1$. Controls with addition of fractions after TCA were run to correct for non-enzymic hydrolysis. All samples were run in duplicate or triplicate. Phosphate (Pi) was measured by the method of Fiske \& Subbarow (1925). Enzyme activity was expressed as nmol Pi released/min per mg protein.

\section{Assay of inorganic pyrophosphatase (EC 3.6.1.1), 5'-nucleotidase and non-specific phosphatase activities}

The reaction medium and conditions were the same as those used in the assay of ATPase and ADPase, except that the reaction was initiated by the addition of one of these compounds (final concentration $1 \mathrm{mM}$ ) : PPi, glucose-6-phosphate, $p$-nitrophenylphosphate, $\beta$-glycerophosphate or AMP in place of ATP or ADP.

\section{Protein determination}

Protein was determined by the method of Lowry et al. (1951) with crystalline bovine serum albumin as a standard. 


\section{Undernutrition}

Rats were undernourished during the period while they were suckled by giving their dams a protein-deficient diet. The conditions were as previously reported (Mello et al. 1989), except that diets of $280 \mathrm{~g}$ (control) and $70 \mathrm{~g}$ (undernourished) casein $/ \mathrm{kg}$ were used. On the day of birth (day 0 ), litters were culled to nine pups and dams were assigned at random to the 280 or $70 \mathrm{~g}$ casein $/ \mathrm{kg}$ diets. The dams assigned to the $280 \mathrm{~g} / \mathrm{kg}$ group received a $280 \mathrm{~g}$ casein $/ \mathrm{kg}$ diet colour-coded with an inert green dye, and dams assigned to the $70 \mathrm{~g} / \mathrm{kg}$ group received a $70 \mathrm{~g}$ casein $/ \mathrm{kg}$ diet colour-coded with an inert red dye. Mothers that failed to rear at least eight pups until the day of the enzyme assays were not included in the experiments.

When the litters were $20 \mathrm{~d}$ old, two female rats from each litter were killed by decapitation. The brain was removed and the cerebellum and olfactory bulbs were discarded. The cerebrum was weighed and the cortex was dissected and processed as described previously.

\section{Statistical analyses}

Values are reported as means and standard deviations. Comparisons between groups were made by two-tailed paired or unpaired Student's $t$ test, depending on the experiments.

\section{RESULTS}

\section{Localization of synaptosomal fraction}

The treatment of fractions with Triton X-100 resulted in a 2- (fraction 1) to 26-fold (fraction 4) increase in specific activity of LDH. The specific activity of LDH of the fraction that sedimented near the interphase of the $100-160 \mathrm{ml}$ Percoll/l layers increased 26-fold with treatment with Triton X-100 (final concentration $10 \mathrm{ml} / \mathrm{l}$ ), indicating a peak of intact synaptosome in this fraction (results not shown). This result is very similar to those reported by Nagy \& Delgado-Escueta (1984) and Nagy et al. (1986). They have found that intact synaptosomes band at the $100-160 \mathrm{ml}$ Percoll/l interphase and that the treatment of this fraction with Triton $\mathrm{X}-100$ resulted in a 19 - to 40 -fold increase in the specific activity of LDH.

\section{Marker enzymes}

Table 1 shows the activity of marker enzymes in cerebral cortex homogenate and synaptosomal fraction. The amount of contamination of synaptosomal fraction by mitochondria, neural plasma membrane, microsome and soluble proteins was calculated in two ways: (a) taking the specific activity ratio of marker enzymes obtained in synaptosomes to that obtained in the homogenate (relative specific activity, RSA) and (b) by measuring the marker enzyme activity that could be recovered in the synaptosomal fraction (Table 1).

Considering the RSA of the various negative marker enzymes, it was found that the synaptosomal fraction presented an impoverishment of these markers (Table 1). This impoverishment relative to the homogenate was confirmed by the low levels of recovered activity of negative markers in synaptosomal fraction: approximately $5 \%$ contamination with SDH activity (mitochondrial marker), less than $2 \%$ contamination with $\mathrm{Na}^{+}, \mathrm{K}^{+}-$ ATPase activity (plasma membrane marker), less than $1 \%$ with LDH (soluble protein marker), approximately 5\% with $\mathrm{AChE}$ (plasma membrane and microsomal marker), and less than $3 \%$ with G6Pase (microsomal marker). The results obtained with mitochondrial and plasma membrane markers are very similar to those found by Nagy \& DelgadoEscueta (1984) and Nagy et al. (1986) in their intact synaptosomes. 
Table 1. Marker enzyme activities in cerebral cortex homogenates $(H)$ and synaptosomal fractions (SYN) from 21-d-old rats

(Mean values and standard deviations. SDH activity is expressed as nmol 2,6-dichloroindophenol reduced/min per $\mathrm{mg}$ protein. $\mathrm{Na}^{+}, \mathrm{K}^{+}$-ATPase and G6Pase activities are expressed as nmol phosphate/min per $\mathrm{mg}$ protein. LDH activity is expressed as nmol lactate consumed/min per $\mathrm{mg}$ protein. AChE activity is expressed as nmol acetylthiocholine consumed $/ \mathrm{min}$ per $\mathrm{mg}$ protein)

\begin{tabular}{|c|c|c|c|c|c|c|c|c|}
\hline \multirow[b]{2}{*}{ Marker enzyme } & \multicolumn{3}{|c|}{$\mathbf{H}$} & \multicolumn{3}{|c|}{ SYN } & \multirow[b]{2}{*}{ RSA } & \multirow{2}{*}{$\begin{array}{l}\text { Percentage } \\
\text { recovered }\end{array}$} \\
\hline & Mean & SD & $n$ & Mean & SD & $n$ & & \\
\hline $\mathrm{SDH}$ & $12 \cdot 7$ & $3 \cdot 1$ & 5 & 7.9 & $2 \cdot 4$ & 5 & 0.62 & $4 \cdot 5$ \\
\hline $\mathrm{Na}^{+}, \mathrm{K}^{+}$-ATPase & $83 \cdot 1$ & $20 \cdot 7$ & 5 & $18 \cdot 9$ & $6 \cdot 5$ & 5 & 0.23 & $1 \cdot 3$ \\
\hline $\mathrm{LDH}$ & $353 \cdot 3$ & $35 \cdot 1$ & 3 & $27 \cdot 0$ & $3 \cdot 1$ & 3 & 0.08 & 0.7 \\
\hline G6Pase & $17 \cdot 2$ & 1.8 & 3 & 6.1 & 1.9 & 3 & 0.35 & $2 \cdot 1$ \\
\hline $\mathrm{AChE}$ & 632 & $14 \cdot 9$ & 4 & $39 \cdot 7$ & 5.9 & 4 & 0.63 & $5 \cdot 0$ \\
\hline
\end{tabular}

RSA, specific activity of SYN: that of $\mathrm{H}$; SDH, succinate dehydrogenase $(E C$ l. 3.99 .1$) ; \mathrm{Na}^{+}, \mathrm{K}^{+}$-ATPase, $\mathrm{Na}^{+}, \mathrm{K}^{+}$-dependent ATPase (EC 3.1.6.4); LDH, lactate dehydrogenase (EC 1.1.1.27); G6Pase, glucose-6phosphatase (EC 3.1.3.9); AChE, acetylcholinesterase (EC 3.1.1.7).

Table 2. Effects of disruption of synaptosomes and inhibitors on the hydrolysis of ATP and $A D P$ by synaptosomal and P2 fractions from 21 -d-old rats

(Mean values and standard deviations. ATPase and ADPase activities are expressed as nmol phosphate/min per $\mathrm{mg}$ protein. The incubation media were used as described on $\mathrm{p}$. 275 , except that sodium azide was not included in the media unless its effect was examined. Synaptosomes were disrupted by hypo-osmotic shock in $6 \mathrm{~mm}$-Tris-hydrochloric acid buffer, $\mathrm{pH} 8.0$ for $1 \mathrm{~h}$ )

\begin{tabular}{|c|c|c|c|c|c|c|c|}
\hline \multirow[b]{2}{*}{ Preparation } & \multirow[b]{2}{*}{ Substrate } & \multicolumn{3}{|c|}{ Synaptosomal fraction } & \multicolumn{3}{|c|}{$\mathbf{P 2}$} \\
\hline & & Mean & SD & $n$ & Mean & SD & $n$ \\
\hline Intact & $\begin{array}{l}\text { ATP } \\
\text { ADP }\end{array}$ & $\begin{array}{r}102 \cdot 0 \\
52 \cdot 1\end{array}$ & $\begin{array}{l}8 \cdot 5 \\
6 \cdot 2\end{array}$ & $\begin{array}{l}4 \\
4\end{array}$ & $\begin{array}{r}160 \cdot 9 \\
73 \cdot 3\end{array}$ & $\begin{array}{l}5 \cdot 2 \\
4 \cdot 3\end{array}$ & $\begin{array}{l}5 \\
4\end{array}$ \\
\hline Disrupted & $\begin{array}{l}\text { ATP } \\
\text { ADP }\end{array}$ & $\begin{array}{r}112 \cdot 6 \\
56 \cdot 3\end{array}$ & $\begin{array}{l}5 \cdot 2 \\
4 \cdot 7\end{array}$ & $\begin{array}{l}4 \\
3\end{array}$ & & & \\
\hline+ Sodium azide ( $5 \mathrm{~mm}$ ) & $\begin{array}{l}\text { ATP } \\
\text { ADP }\end{array}$ & $\begin{array}{l}93 \cdot 2 \\
48 \cdot 0\end{array}$ & $\begin{array}{l}7 \cdot 7 \\
6 \cdot 5\end{array}$ & $\begin{array}{l}4 \\
4\end{array}$ & $\begin{array}{c}124 \cdot 3^{* *} \\
64 \cdot 8\end{array}$ & $\begin{array}{l}7 \cdot 2 \\
7 \cdot 6\end{array}$ & $\begin{array}{l}5 \\
3\end{array}$ \\
\hline +Ouabain (1 mM) & $\begin{array}{l}\text { ATP } \\
\text { ADP }\end{array}$ & $\begin{array}{l}98.7 \\
51.7\end{array}$ & $\begin{array}{r}10 \cdot 0 \\
6.2\end{array}$ & $\begin{array}{l}5 \\
3\end{array}$ & & & \\
\hline+ Lanthanum $(0 \cdot 1 \mathrm{~mm})$ & $\begin{array}{l}\text { ATP } \\
\text { ADP }\end{array}$ & $\begin{array}{r}118.5 \\
54.7\end{array}$ & $\begin{array}{r}16 \cdot 2 \\
3.7\end{array}$ & $\begin{array}{l}2 \\
2\end{array}$ & & & \\
\hline+ Potassium fluoride $(30 \mathrm{~mm})$ & $\begin{array}{l}\text { ATP } \\
\text { ADP }\end{array}$ & $\begin{array}{l}9 \cdot 2+\dagger+ \\
2 \cdot 9+\dagger+\end{array}$ & $\begin{array}{l}3.5 \\
1 \cdot 1\end{array}$ & $\begin{array}{l}4 \\
4\end{array}$ & & & \\
\hline
\end{tabular}

** Mean value was significantly different from intact $\mathrm{P} 2(P<0.01)$.

$\dagger \dagger \dagger$ Mean value was significantly different from intact synaptosome $(P<0.001)$.

$\ddagger$ For details, see p. 274.

\section{Effect of disruption and inhibitors on ATP and ADP hydrolysis}

Table 2 shows the effects of disruption and inhibitors on Ca-ATP and Ca-ADP hydrolysis activity of the synaptosomal fraction. Disruption of the synaptosomal fraction caused an increase of about $10 \%$ in the hydrolysis of both ATP and ADP; however, this increase was not statistically significant. Nagy et al. (1986) have described a $7 \%$ increase in the $\mathrm{Ca}^{2+}$ - 
ATPase activity in synaptosomes after disruption of the fraction. Ouabain, a classical $\mathrm{Na}^{+}, \mathrm{K}^{+}$-ATPase inhibitor, had practically no effect on ATP and ADP hydrolysis. This result is in accordance with the findings of Nagy et al. (1986) and Grondal \& Zimmerman (1986) who reported a similar effect of ouabain on $\mathrm{Ca}^{2+}$-ATPase. The effect of sodium azide, a mitochondrial inhibitor, was assessed in the synaptosomal and P2 fraction. Azide caused an inhibition of $9 \%$ in the hydrolysis of ATP and ADP of the synaptosomal fraction. This inhibition was not statistically significant. Nagy et al. (1986) reported that 1 mM-sodium azide causes a $14 \%$ inhibition of $\mathrm{Ca}^{2+}$-ATPase activity of the synaptosomal fraction; however, these authors did not report whether this inhibition was significant. On the other hand, sodium azide caused a significant $23 \%$ inhibition of $\mathrm{Ca}^{2+}$-ATPase activity of the P2 fraction $(P<0.01)$. This effect may be related to an inhibition of an ATPase associated with mitochondria. Lanthanum, a $\mathrm{Ca}^{2+}+\mathrm{Mg}^{2+}$-ATPase inhibitor, did not alter the hydrolysis of either ATP or ADP. Potassium fluoride, which inhibits apyrase from pig pancreas (LeBel et al. 1980), caused a significant and parallel reduction in the hydrolysis of both ATP and ADP $(P<0.001)$.

\section{Inorganic pyrophosphatase, non-specific phosphatases and 5'-nucleotidase}

The presence of inorganic pyrophosphatase in the synaptosomal preparations was excluded because no Pi was released when 1.0 mM-PPi was added to the incubation medium in place of ATP and ADP ( $n$ 6). Neither was there hydrolysis of the other phosphate esters tested: glucose-6-P ( $n$ 5), $p$-nitrophenylphosphate $(n$ 4), and $\beta$-glycerophosphate $(n$ 4). The presence of a $5^{\prime}$-nucleotidase in our assay system was excluded because AMP was not hydrolysed ( $n$ 4).

The presence of contaminant adenylate kinase (EC 2.7.4.3) was excluded because the potent and selective adenylate kinase inhibitor, Ap5A (Lienhard \& Secemski, 1973) at a concentration of $10 \mu \mathrm{M}$ did not affect either ADP or ATP hydrolysis by the synaptosomal preparation. Mean values for ATP and ADP hydrolysis in the presence of Ap5A were $91 \cdot 3$ (SD 5.8) and 44.7 (SD 3.9) respectively, and in the absence of Ap5A the values for ATP and ADP were $94 \cdot 2$ (SD 4.1) and $42 \cdot 0$ (SD 3.3) respectively $(n 3)$.

\section{Mixed-substrate assay}

To exclude the possibility that the hydrolysis of ATP and ADP was due to concerted activity of an ATPase with an ADPase, ATP and ADP were added to the incubation medium at saturating concentrations at the same time. In this condition the rate of $\mathrm{Pi}$ release was intermediate between the rates obtained when each one was added alone: thus with $1 \mathrm{mM}$-ATP the mean was 90.3 (SD 3.4) $\mathrm{nmol} \mathrm{Pi} / \mathrm{min}$ per $\mathrm{mg}$ protein, with $1 \mathrm{mM}$-ADP the mean was $46 \cdot 3$ (SD 2.8) $\mathrm{nmol} \mathrm{Pi} / \mathrm{min}$ per mg protein, and with $1 \mathrm{mM}-\mathrm{ATP}+1 \mathrm{mM}-\mathrm{ADP}$ a mean of $70 \cdot 3$ (SD $3 \cdot 2$ ) was obtained ( $n$ 5). In the presence of a single enzyme, rates of $\mathrm{Pi}$ production in the mixed-substrate reaction should be close to the average value found for each individual substrate, whereas if two enzymes existed the rate for the mixed reaction should be the sum of the values found for the individual substrates. Results from these experiments support the existence of one enzyme with two substrates (Dixon \& Webb, 1979) in synaptosomal preparations from young rats. This procedure is a classical treatment for characterizing apyrases (Harper et al. 1978; LeBel et al. 1980; Sarkis et al. $1986 a)$.

\section{Effect of undernutrition on body and brain weights of 20-d-old rats}

Table 3 shows the body-weights and brain weights of 20 -d-old rats. Undernutrition reduced the body-weight of deprived rats to $33 \%$ of that of well-nourished animals $(P<0 \cdot 001)$. The brain weight of undernourished rats was decreased to $82 \%$ of that of well-nourished animals $(P<0.001)$. 
Table 3. Effect of preweaning undernutrition (dams given $70 \mathrm{~g}$ casein $/ \mathrm{kg}$ diet; wellnourished group $280 \mathrm{~g}$ casein $/ \mathrm{kg}$ diet) on body and cerebral weight of 20 -d-old rats (Mean values and standard deviations. Lactate dehydrogenase (EC 1.1.1.27, LDH) activity expressed in $\mathrm{nmol} / \mathrm{min}$ per $\mathrm{mg}$ protein. Triton-treated synaptosomes were pre-incubated for $5 \mathrm{~min}$ in the presence of $10 \mathrm{ml}$ Triton $\mathrm{X}-100 / 1)$

\begin{tabular}{|c|c|c|c|c|c|c|}
\hline \multirow[t]{2}{*}{ Dietary group ... } & \multicolumn{3}{|c|}{$280 \mathrm{~g}$ casein $/ \mathrm{kg}$} & \multicolumn{3}{|c|}{$\begin{array}{c}70 \mathrm{~g} \\
\text { casein/kg }\end{array}$} \\
\hline & Mean & SD & $n$ & Mean & SD & $n$ \\
\hline Body-wt (g) & 48.6 & $2 \cdot 4$ & 9 & $16 \cdot 0^{* * *}$ & $2 \cdot 1$ & 9 \\
\hline \multirow{2}{*}{\multicolumn{7}{|c|}{ LDH }} \\
\hline & & & & & & \\
\hline Intact synaptosomes & $30 \cdot 0$ & $11 \cdot 7$ & 6 & $31 \cdot 1$ & $7 \cdot 3$ & 6 \\
\hline Triton-treated synaptosomes & $530 \cdot 5$ & $127 \cdot 8$ & 6 & $532 \cdot 7$ & $66 \cdot 7$ & 6 \\
\hline
\end{tabular}

*** Mean value significantly different from that for well-nourished animals $(P<0.005)$.

Table 4. Effects of preweaning undernutrition (dams given $70 \mathrm{~g}$ casein $/ \mathrm{kg}$ diet; wellnourished group $280 \mathrm{~g}$ casein $/ \mathrm{kg}$ diet) on $\mathrm{Ca}^{2+}-$ ATPase and $\mathrm{Ca}^{2+}-$ ADPase activity of various subfractions of cerebral cortex $\dagger$ of 20-d-old rats

(Mean values and standard deviations. ATPase and ADPase activities are expressed in nmol phosphate/min per mg protein)

\begin{tabular}{|c|c|c|c|c|c|c|c|}
\hline \multirow{2}{*}{$\begin{array}{l}\text { Dietary group... } \\
\text { Cerebral fraction }\end{array}$} & \multirow[b]{2}{*}{ Substrate } & \multicolumn{3}{|c|}{$280 \mathrm{~g}$ casein $/ \mathrm{kg}$} & \multicolumn{3}{|c|}{$70 \mathrm{~g}$ casein $/ \mathrm{kg}$} \\
\hline & & Mean & SD & $n$ & Mean & SD & $n$ \\
\hline $\mathbf{H}$ & $\begin{array}{l}\text { ATP } \\
\text { ADP }\end{array}$ & $\begin{array}{r}148.1 \\
66.7\end{array}$ & $\begin{array}{l}5 \cdot 0 \\
2 \cdot 4\end{array}$ & $\begin{array}{l}4 \\
4\end{array}$ & $\begin{array}{c}146 \cdot 3 \\
68 \cdot 8\end{array}$ & $\begin{array}{l}2 \cdot 4 \\
1 \cdot 7\end{array}$ & $\begin{array}{l}4 \\
4\end{array}$ \\
\hline S1 & $\begin{array}{l}\text { ATP } \\
\text { ADP }\end{array}$ & $\begin{array}{r}128.0 \\
61.5\end{array}$ & $\begin{array}{l}0.7 \\
2.9\end{array}$ & $\begin{array}{l}4 \\
4\end{array}$ & $\begin{array}{r}130 \cdot 4 \\
65 \cdot 2\end{array}$ & $\begin{array}{l}7 \cdot 7 \\
7 \cdot 4\end{array}$ & $\begin{array}{l}4 \\
4\end{array}$ \\
\hline $\mathrm{P} 2$ & $\begin{array}{l}\text { ATP } \\
\text { ADP }\end{array}$ & $\begin{array}{r}136.2 \\
66.7\end{array}$ & $\begin{array}{l}8 \cdot 5 \\
7 \cdot 4\end{array}$ & $\begin{array}{l}9 \\
8\end{array}$ & $\begin{array}{l}115 \cdot 1^{* * *} \\
55 \cdot 2^{*}\end{array}$ & $\begin{array}{l}6 \cdot 2 \\
6 \cdot 1\end{array}$ & $\begin{array}{l}9 \\
8\end{array}$ \\
\hline SYN & $\begin{array}{l}\text { ATP } \\
\text { ADP }\end{array}$ & $\begin{array}{l}96 \cdot 1 \\
47 \cdot 2\end{array}$ & $\begin{array}{l}6 \cdot 6 \\
4 \cdot 5\end{array}$ & $\begin{array}{l}7 \\
6\end{array}$ & $\begin{array}{l}78.0^{* *} \\
37 \cdot 8^{*}\end{array}$ & $\begin{array}{l}5.8 \\
3.9\end{array}$ & $\begin{array}{l}7 \\
6\end{array}$ \\
\hline
\end{tabular}

Mean values were significantly different from those for well-nourished animals: $* P<0 \cdot 05,{ }^{*} P<0 \cdot 01$ or *** $P<0.005$.

$\dagger$ Fractions obtained by differential centrifugation: H, homogenate; S1, low-speed supernatant fraction; P2, postmitochondrial pellet; SYN, synaptosomal fraction. For details see pp. 274-275.

\section{Effects of undernutrition on ATPase and ADPase activity}

Table 4 shows the effects of undernutrition on the ATPase and ADPase activities of various fractions of the cerebral cortex of 20-d-old rats. Undernutrition had no significant effects on either ATPase or ADPase activity of either the homogenate or S1 fraction. On the other hand, undernutrition caused significant reductions of $15 \%$ in $\mathrm{Ca}^{2+}$-ATPase $(P<$ $0.005)$ and of $17 \%$ in $\mathrm{Ca}^{2+}$-ADPase $(P<0.05)$ activities of $\mathrm{P} 2$, and a significant reduction of $19 \%$ in both ATPase $(P<0.01)$ and ADPase $(P<0.05)$ activities of the synaptosomal fraction. 


\section{DISCUSSION}

The results obtained from young rats suggest that the hydrolysis of both ATP and ADP in the synaptosomal preparations is due to an ATP diphosphohydrolase. The following evidence excluded the possibility of enzyme combinations that could mimic an apyrase activity in our assay: (1) no adenylate kinase was detected, excluding a combination of this enzyme with an ATPase on the hydrolysis of ADP, (2) no inorganic pyrophosphatase activity was detected, excluding the possibility of a concerted action of an ATP pyrophosphatase (EC 3.6.1.8) and inorganic pyrophosphatase, and (3) the rate of hydrolysis of both nucleotides (ATP and ADP), when they were added together, was equal to the arithmetic mean of the activities found for each one separately, suggesting the presence of a single enzyme with two substrates. Regarding the mixed-substrate experiments, there remains the possibility of cross-inhibition between two substrates at the level of two different enzymes. However, the effects of ATPase inhibitors (Table 2) suggest that well-known ATPases are not involved in the hydrolysis of ATP and give further support to the presence of one enzyme that hydrolyses ATP and ADP.

The undernutrition imposed in the present work resulted in a deficit in body-weight greater than previously reported in rats undernourished when they are being suckled. At $20 \mathrm{~d}$ of age, undernourished rats had a deficit in body-weight of $67 \%$ compared with wellnourished animals (Table 3 ). The deficit achieved in the present work is comparable to those obtained with combined gestational and lactational undernutrition (Adlard \& Dobbing, 1971, 1972).

The results of the ATPase and ADPase assays demonstrated that undernutrition while rats are being suckled decreases these activities in $\mathrm{P} 2$ and synaptosomal fractions (Table 4). The specific activities of ATPase and ADPase of both P2 and synaptosomal fractions were lowered by undernutrition to about $18 \%$ of well-nourished values. The other fractions studied (total homogenate and S1) were not affected by undernutrition, suggesting that the deficit is associated with fractions enriched in synaptosomes. It is interesting to note that undernutrition caused a parallel decrease in the hydrolysis of both nucleotides.

Various subcellular fractions of the brain possess ATPase activities. $\mathrm{Ca}^{2+}$-ATPase activities have been reported to be associated with mitochondria, microsomes, and plasma membranes (Nagy et al. 1983). Thus, it became important to assess the contamination of these structures in our synaptosomal preparation. Mitochondrial contamination in the synaptosomal fraction did not exceed $5 \%$ (Table 1). Furthermore, a mitochondrial ATPase inhibitor was included in the reaction medium in the present study, excluding practically all mitochondrial ATPase contamination. This was shown by the fact that sodium azide caused a $23 \%$ inhibition in the $\mathrm{Ca}^{2+}$-ATPase activity of $\mathrm{P} 2$ (a fraction enriched in mitochondria and synaptosomes), while in the synaptosomal fraction the inhibition of ATP hydrolysis was not statistically significant $(9 \%$, Table 2$)$. The contamination with plasma membranes was low in our synaptosomal preparation as judged by $\mathrm{Na}^{+}, \mathrm{K}^{+}$-ATPase (less than $2 \%$ ), suggesting that the contamination by disrupted synaptosomes and postsynaptic attachments was low (Table 1). In addition, the ratio of $\mathrm{LDH}$ measured in the intact synaptosomes to that in Triton-treated synaptosomes demonstrated that less than $10 \%$ of this activity is present in intact synaptosomes (Table 3), which also indicates that most of the synaptosomes in this fraction were intact. Contamination of the synaptosomal fraction with microsomes, as judged by G6Pase, was also low (less than $3 \%$ ). Furthermore, we also measured $\mathrm{Ca}^{2+}$-ATPase and ADPase in microsomal fractions obtained from the cerebral cortex of well-nourished and undernourished animals (results not shown). No significant differences were detected between nutritional groups in either nucleotidase activity, suggesting that the deficits found in these activities in synaptosomal and $\mathrm{P} 2$ preparations are not due to microsomal contamination. 
Other reports in the literature have demonstrated that perinatal undernutrition can retard the development of several enzymes involved in neurotransmitter metabolism and neuronal function (Sereni et al. 1966; Adlard \& Dobbing, 1971; Kissane \& Hawrylewicz, 1975; Stern et al. 1975; Vitiello \& Gombos, 1987; Chanez et al. 1988). The results of the present study demonstrated that undernutrition between birth and weaning can also decrease the activity of both ATP and ADP hydrolysis in fractions enriched in synaptosomes of 20 -d-old rats.

Although no specific experiments were done to demonstrate that these activities are localized at the external surface of synaptosomal plasma membrane, the low contamination with plasma membranes, the low activity of LDH (indicating few broken synaptosomes in our preparation), the fact that disruption of synaptosomes did not increase the hydrolysis of either ATP or ADP, and considering that the adenine nucleotides added to the incubation medium cannot enter the synaptosomes (Krueger et al. 1977; Grondal \& Zimmerman, 1986) all suggest that these activities are due to ecto-enzymes.

Recently it has been demonstrated that an apyrase is present at the external surface of synaptosomes of the hypothalamus of rats (Schadeck et al. 1989). In the present study, undernutrition was shown to cause a similar decrease in both ATPase and ADPase activities which may suggest that a single enzyme is hydrolysing both nucleotides. However, in the present work we have obtained only partial evidence that ATPase and ADPase activities resulted from the action of a single enzyme. Thus, it is also possible that two enzymes are being affected to the same extent by undernutrition.

The results of the present study demonstrate that undernutrition while rats are being suckled decreases ATPase-ADPase activities associated with synaptosomal preparations. Probably these activities are due to an ecto-enzyme and may be involved in ATP and ADP degradation in the synaptic cleft. It has been suggested that these activities, together with a 5'-nucleotidase, could be a component of an enzyme chain that produces adenosine in the synaptic cleft (Keller \& Zimmerman, 1983; Nagy et al. 1986; Grondal \& Zimmerman, 1986; Schadeck et al. 1989). Whether the observed decrease in both ATPase and ADPase of synaptosomal preparations of the cerebral cortex of 20 -d-old rats would lead to deficits in the production of adenosine in the synaptic cleft remains to be investigated.

The authors thank Professor Richard Rodnight for revising the English text. The work was supported by FINEP, CNPq and FAPERGS.

\section{REFERENCES}

Abdel-Latif, A. A., Brody, J. \& Ramahi, H. (1970). Studies of $\mathrm{Na}^{+}, \mathrm{K}^{+}-\mathrm{ATP}$ ase in nerve endings and appearance of electrical activity in developing rat brain. Journal of Neurochemistry 14, 1133-1141.

Adlard, B. P. F. \& Dobbing, J. (1971). Vulnerability of developing brain. III. Development of four enzymes in the brains of normal and undernourished rats. Brain Research 28, 97-107.

Adlard, B. P. F. \& Dobbing, J. (1972). Vulnerability of developing brain. Regional acetylcholinesterase activity in the brains of adult rats undernourished in early life. British Journal of Nutrition 38, 139-143.

Chanez, C., Barone, P., Flexor, M.-R. \& Bourre, J.-M. (1988). Na ${ }^{+}, \mathrm{K}^{+}-$ATPase activity in synaptosomes and myelin of developing control and intra-uterine growth retarded rats: effects of lead and serotonin. Neurochemical International 12, 39-45.

Cragg, B. G. (1972). The development of cortical synapses during starvation in the rat. Brain Research 73 , $139-144$.

Dixon, M. \& Webb, E. C. (1979). Enzymes. 3rd ed. New York: Academic Press.

Dowdall, M. J. (1978). Adenine nucleotide in cholinergic transmission : presynaptic aspects. Journal de Physiologie 74, 497-501.

Dutra-Filho, C. S., Wannamacher, C. M. D., Pires, R. F., Gus, G., Kalil, A. M. \& Wajner, M. (1989). Reduced locomotor activity of rats made histidinemic by injection of histidine. Journal of Nutrition 119, $1223-1227$.

Dyson, S. E. \& Jones, D. G. (1976). Some effects of undernutrition on synaptic development-a quantitative ultrastructural study. Brain Research 114, 365-376.

Ellman, G. L., Courtney, K. D., Andres, V. Jr \& Featherstone, R. M. (1961). A new and rapid colorimetric determination of acetylcholinesterase activity. Biochemical Pharmacology 7, 88-95. 
Fiedler, E. P., Marks, M. J. \& Collins, A. (1987). Postnatal development of cholinergic enzymes and receptors in mouse brain. Journal of Neurochemistry 49, 983-990.

Fiske, C. H. \& Subbarow, Y. (1925). The colorimetric determination of phosphorus. Journal of Biological Chemistry 66, 375-400.

Grondal, E. J. \& Zimmerman, H. (1986). Ectonucleotidase activities associated with cholinergic synaptosomes isolated from Torpedo electric organ. Journal of Neurochemistry 47, 871-881.

Harper, F., Lamy, F. \& Calvert, R. (1978). Some properties of $\mathrm{Ca}^{2+}$ and/or $\mathrm{Mg}^{2+}$-requiring nucleoside di- and triphosphatase(s) associated with the membranes of rat pancreatic zymogen granules. Canadian Journal of Biochemistry 56, 565-576.

Hubscher, G. \& West, G. R. (1965). Specific assays of some phosphatases in subcellular fractions of small intestinal mucosa. Nature 205, 779-780.

Keller, F. \& Zimmerman, H. (1983). Ecto-adenosine triphosphatase activity at the cholinergic nerve endings of the Torpedo electric organ. Life Sciences 33, 2635-2641.

Kissane, J. Q. \& Hawrylewicz, E. S. (1975). Development of $\mathrm{Na}^{+}, \mathrm{K}^{+}$-ATPase in neonatal rat brain synaptosomes after protein malnutrition. Pediatric Research 9, 146-150.

Krueger, B. K., Forn, J. \& Greengard, P. (1977). Depolarization induced phosphorylation of specific proteins mediated by calcium ion influx in rat brain synaptosomes. Joumal of Biological Chemistry 252, $2764-2773$.

LeBel, D., Poirier, G. G., Phaneuf, S., St Jean, P., Laliberté, J. P. \& Beaudoin, R. (1980). Characterization and purification of a calcium-sensitive ATP diphosphohydrolase from pig pancreas. Journal of Biological Chemistry 255, $1227-1233$.

Lienhard, G. E. \& Secemski, H. (1973). P, P-di(adenosine-5')-pentaphosphate, a potent multisubstrate inhibitor of adenylate kinase. Journal of Biological Chemistry 248, 1121-1123.

Lowry, O. H., Rosebrough, N. J., Farr, A. L. \& Randall, R. J. (1951). Protein measurement with the folin phenol reagent. Journal of Biological Chemistry 193, 265-275.

Mello, C. F., Rotta, F. T., Souza, D. O. \& Rocha, J. B. T. (1989). Undernutrition during suckling and latent learning ability of rehabilitated adult male rats. Behavioral and Neural Biology 52, 39-50.

Miller, M., Leahy, J. P., Stern, W. C., Morgane, P. J. \& Resnick, O. (1977). Tryptophan availability: relation to elevated brain serotonin in developmentally protein-malnourished rats. Experimental Neurology 57, 142-157.

Morgan, I. G. (1976). Synaptosomes and cell separation. Neuroscience 1, 159-165.

Nagata, H., Mimori, Y., Nakamura, S. \& Kameyama, M. (1984). Regional and subcellular distribution in mammalian brain of the enzymes producing adenosine. Journal of Neurochemistry 42, 1001-1007.

Nagy, A. \& Delgado-Escueta, A. V. (1984). Rapid preparation of synaptosomes from mammalian brain using nontoxic isoosmotic gradient material (Percoll). Journal of Neurochemistry 43, 1114-1123.

Nagy, A., Shuster, T. A. \& Delgado-Escueta, A. V. (1986). Ecto-ATPase of mammalian synaptosomes: identification and enzyme characterization. Journal of Neurochemistry 47, 976-986.

Nagy, A., Shuster, T. A. \& Rosenberg, M. O. (1983). Adenosine triphosphatase activity at the external surface of chicken brain synaptosomes. Journal of Neurochemistry 40, 226-234

Robain, O. \& Ponsot, G. (1978). Effects of undernutrition on glial maturation. Brain Research 149, 379-397.

Salas, M., Diaz, S. \& Nieto, A. (1974). Effects of neonatal food deprivation on cortical spines dendritic development of the rat. Brain Research 73, 139-144.

Sarkis, J. J. F., Guimaraes, J. A. \& Ribeiro, J. M. C. (1986a). Salivary apyrase of Rhodnius prolixus: kinetics and purification. Biochemical Journal 233, 885-891.

Sarkis, J. J. F., Schadeck, R. J. G., Dias, R. D., Araujo, H. M. M. \& Souza, D. O. (1986b). Ecto-apyrase activity in the synaptosomal fraction of hypothalamus of adult rats. Anais da Academia Brasileira de Ciencias $\mathbf{5 8}$, $598-599$.

Schadeck, R. J. G., Sarkis, J. J. F., Dias, R. D., Araujo, H. M. M. \& Souza, D. O. (1989). Synaptosomal apyrase in the hypothalamus of adult rats. Brazilian Journal of Medical and Biological Research 22, 303-314.

Sereni, F., Principi, N., Perteletti, L. \& Sereni, L. P. (1966). Undernutrition and the developing rat brain. Influence on acetylcholinesterase and succinic acid dehydrogenase activities and on norepinephrine and 5-OH-tryptamine tissue concentrations. Biology of the Neonate 10, 254-265.

Sorensen, R. G. \& Mahler, H. R. (1981). Calcium-stimulated adenosine triphosphatase in synaptic membranes. Journal of Neurochemistry 37, 1407-1418.

Sorensen, R. G. \& Mahler, H. R. (1982). Localization of endogenous ATPase in the nerve terminal. Journal of Bioenergetics and Biomembranes 14, 527-547.

Stern, W. C., Miller, M., Forbes, W. B., Morgane, P. J. \& Resnick, O. (1975). Ontogeny of the levels of biogenic amines in various parts of the brain and in peripheral tissues in normal and protein malnourished rats. Experimental Neurology 49, 314-326.

Vanella, A., Barcellona, M. L., Avitabile, M., Avola, R., Ragusa, N., Serra, I. \& Giuffrida, A. M. (1983). Effect of undernutrition on some enzymes of purine metabolism in different regions of developing rat brain. Journal of Neuroscience Research 9, 183-191.

Vendite, D., Rocha, J. B. T. \& Souza, D. O. (1988). Effects of undernutrition during suckling and of training on the hypothalamic $\beta$-endorphin of young and adult rats. Peptides 9, 751-755.

Vernadakis, A. \& Arnold, E. B. (1980). Age-related changes in neuronal and glial enzyme activities. In $A d v a n c e s$ in Cellular Neurobiology, vol. 1, pp. 229-283 [S. Fedoroff and L. Hertz, editors]. New York: Academic Press. 
Vitiello, F. \& Gombos, G. (1987). Cerebellar development and nutrition. In Basic and Clinical Aspects of Nutrition and Brain Development, vol. 16, pp. 99-130 [D. V. Rassin, B. Haber and B. Drujan, editors]. New York: Alan R. Liss.

Whitaker, J. F. (1969). A general colorimetric procedure for the estimation of enzymes which are linked to the NADH-NAD ${ }^{+}$system. Clinica Chimica Acta 24, 23-37.

Wiggins, R. C. (1982). Myelin development and nutritional insufficiency. Brain Research Reviews 4, $151-175$. 